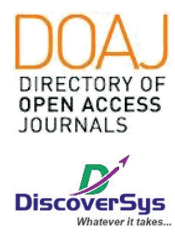

Published by DiscoverSys

\section{Hubungan antara bayi berat lahir rendah dengan asfiksia neonatarum di RSUD Wangaya Kota Denpasar}

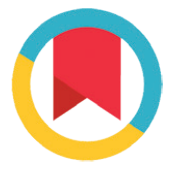

CrossMark

\author{
Ida Bagus Wiadnyana, I Wayan Bikin Suryawan, A.A Made Sucipta
}

\section{ABSTRACT}

Background: Low Birth Weight (LBW) in infants is still a problem in the health sector, especially perinatal health. The prevalence of low birth weight babies (BBLR) is estimated to be $15 \%$ of all births in the world with a 3.3\% -38\% limit and is more common in developing countries or low socio-economic countries. Frequent complications of LBW such as hypothermia, respiratory disorders, gastrointestinal disorders, immunological disorders, liver immaturity, renal immunity and bleeding. In LBW, there can be a lack of surfactant and not yet perfect growth and lung development so that difficulties start breathing which result to occur Neonatal Asphyxia. The purpose of this study was to determine the relationship of degree of LBW with the degree of Neonatal Asphyxia.

Methods: The type of research used is observational analytic with cross sectional study design. In this study, sampling was performed at
LBW at Wangaya Hospital April 2016 - April 2017 period in NICU and Perinatology room until the number of research samples fulfilling the inclusion and exclusion criteria with total sample of 87 samples. The sample is obtained by consecutive sampling method, then collecting the necessary data. The data obtained were analyzed analytically, then presented in tabulation data and described using tables and narration.

Result: There was a significant correlation between degree of BBLR and degree of Asphyxia Neonatarum $(p=0,03), B B L R$ was risk factor to degree of asphyxia with prevalence prevalence $(\mathrm{RP})=2.08(95 \% \mathrm{Cl}=$ $1.08-1,30)$.

Conclusion: There was a significant correlation between degree of LBW and degree of Neonatal Asphyxia.

Keywords: Low Birth Weight (LBW), Neonatal Asphyxia

Cite This Article: Wiadnyana, I.B., Suryawan, I.W.B., Sucipta, A.A.M. 2018. Hubungan antara bayi berat lahir rendah dengan asfiksia neonatarum di RSUD Wangaya Kota Denpasar. Intisari Sains Medis 9(2): 95-99. D0I: 10.1556/ism.v9i2.167

\title{
ABSTRAK
}

Latar Belakang: Bayi Berat Lahir Rendah (BBLR) pada bayi masih merupakan masalah di bidang kesehatan terutama kesehatan perinatal. Prevalensi bayi dengan berat badan lahir rendah (BBLR) diperkirakan 15\% dari seluruh kelahiran di dunia dengan batasan 3,3\%-38\% dan lebih sering terjadi di negara berkembang atau negara dengan sosio-ekonomi rendah. Komplikasi yang sering terjadi pada BBLR seperti hipotermi, gangguan pernafasan, gangguan alat pencernaan, gangguan immunologi, immatur hati, immatur ginjal serta perdarahan. Pada BBLR dapat terjadi kekurangan surfaktan dan belum sempurna pertumbuhan dan perkembangan paru sehingga kesulitan memulai pernafasan yang berakibat untuk terjadi asfiksia neonatorum. Tujuan dari penelitian ini adalah untuk mengetahui hubungan derajat BBLR dengan derajat asfiksia neonatorum.

Metode: Jenis penelitian yang digunakan adalah observasional analitik dengan rancangan penelitian cross sectional. Pada penelitian ini, pengambilan sampel dilakukan pada BBLR di RSUD Wangaya periode April 2016 - April 2017 di ruang Nicu dan Perinatologi sampai jumlah sampel penelitian yang memenuhi kriteria inklusi dan eksklusi dengan jumlah sample total 87 sampel. Sampel diperoleh melalui metode consecutive sampling, selanjutnya dilakukan pengumpulan data yang diperlukan. Data yang diperoleh dianalisis secara analitik, selanjutnya disajikan dalam tabulasi data serta dijabarkan menggunakan tabel dan narasi.

Hasil: Terdapat hubungan yang signifikan antara derajat BBLR dengan derajat Asfiksia Neonatarum $(p=0,03)$, BBLR merupakan factor resiko terhadap derajat asfiksia dengan nilai resiko prevalensi $(\mathrm{RP})=2,08$ (IK $95 \%=1,08-1,30)$.

Simpulan: Terdapat hubungan yang signifikan antara derajat BBLR dengan derajat Asfiksia Neonatarum.
Bagian/SMF IImu Kesehatan Anak RSUD Wangaya, Bali-Indonesia

*Correspondence to:

gz_didox@yahoo.com
Kata kunci: BBLR, Asfiksia Neonatarum.

Cite Pasal Ini: Wiadnyana, I.B., Suryawan, I.W.B., Sucipta, A.A.M. 2018. Hubungan antara bayi berat lahir rendah dengan asfiksia neonatarum di RSUD Wangaya Kota Denpasar. Intisari Sains Medis 9(2): 95-99. D0I: 10.1556/ism.v9i2.167

\section{PENDAHULUAN}

Asfiksia adalah suatu keadaan bayi baru lahir yang gagal bernafas secara spontan dan teratur segera setelah lahir. Asfiksia merupakan salah satu penyebab mortalitas dan morbiditas bayi baru lahir dan 
akan membawa beberapa dampak pada periode neonatal baik di negara berkembang maupun negara maju. ${ }^{1}$

Menurut laporan World Health Organization (WHO) pada tahun 2000 Angka Kematian Bayi (AKB) didunia 54 per 1000 kelahiran hidup dan tahun 2006 menjadi 49 per 1000 kelahiran hidup. Setiap tahunnya sekitar 3\% (3,6 juta) dari 120 juta bayi lahir mengalami asfiksia, hampir 1 juta bayi ini kemungkinan meninggal. ${ }^{1}$

Berdasarkan hasil survei Demografi dan Kesehatan Indonesia (SDKI) tahun 2012, Angka Kematian Neonatus (neonatal mortality rate, NMR) pada tahun 2012 sebesar 19 per 1000 kelahiran hidup menurun dari 20 per 1000 kelahiran hidup di tahun 2007 dan 23 per 1000 kelahiran hidup berdasarkan hasil SDKI 2002. ${ }^{2}$ Perhatian terhadap upaya penurunan neonatal mortality rate (usia dibawah 28 hari) menjadi penting karena kematian neonatal memberi kontribusi terhadap

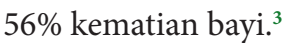

Masalah utama penyebab kematian pada bayi dan balita adalah pada masa neonatus (bayi baru lahir umur 0- 28 hari). Menurut hasil Riskesdas 2007 menunjukkan bahwa 78,5\% dari kematian neonatal terjadi pada umur 0 - 6 hari. ${ }^{4}$

Komplikasi yang menjadi penyebab kematian terbanyak adalah asfiksia, bayi berat lahir rendah dan infeksi. ${ }^{4}$

Berat Badan Lahir Rendah (BBLR) pada bayi masih merupakan masalah di bidang kesehatan terutama kesehatan perinatal. Prevalensi bayi dengan berat badan lahir rendah (BBLR) diperkirakan $15 \%$ dari seluruh kelahiran di dunia dengan batasan 3,3\%-38\% dan lebih sering terjadi di negara berkembang atau negara dengan sosio-ekonomi rendah. ${ }^{5} \mathrm{Di}$ Indonesia prevalensi BBLR berkurang dari $11,1 \%$ pada tahun 2010 menjadi $10,2 \%$ pada tahun 2013. ${ }^{6}$

Prevalensi kejadian BBLR di provinsi Bali yaitu 12,1\% pada hasil data Riskesdas tahun 2010, di kota Denpasar jumlah BBLR sebanyak 181 dari 18.386 jumlah kelahiran hidup. ${ }^{7}$ Selain prevalensinya tinggi, bayi dengan berat badan lahir rendah juga merupakan salah satu faktor yang mempunyai kontribusi terhadap kematian bayi khususnya pada masa perinatal. Komplikasi yang sering terjadi pada BBLR seperti hipotermi, gangguan pernafasan, gangguan alat pencernaan, gangguan immunologi, immatur hati, immatur ginjal serta perdarahan, selain itu bayi dengan BBLR dapat mengalami gangguan mental dan fisik pada usia tumbuh kembang selanjutnya. ${ }^{8}$

Pada BBLR dapat terjadi kekurangan surfaktan dan belum sempurna pertumbuhan dan perkembangan paru sehingga kesulitan memulai pernafasan yang berakibat untuk terjadi asfiksia neonatorum. Hal inilah yang membuat peneliti ingin mengetahui hubungan antara BBLR dengan tingkat keparahan asfiksia neonatorum. ${ }^{9}$

\section{METODE}

Penelitian ini merupakan penelitian analitik observasional dengan desain cross-sectiona untuk mencari hubungan antar variabel, yaitu variabel bebas (faktor resiko) dan variabel tergantung (efek). Penelitian ini dilakukan di di Ruang Nicu dan Perinatologi anak RSUD Wangaya kota Denpasar. Besar sampel mínimum pada penelitian ini adalah 87 sampel. 87 sampel dipilih menggunakan Teknik konsekutif, yaitu semua Bayi yang mengalami BBLR, dirawat inap di ruang Nicu dan Perinatologi RSUD Wangaya Kota Denpasar periode April 2016 - April 2017 yang memenuhi kriteria inklusi dan eksklusi. Sampel dipilih dengan mempertimbangkan kriteria inklusi berupa BBLR di RSUD Wangaya periode April 2016 - April 2017. Sedangkan kriteria ekslusi adalah Rekam medis tidak lengkap.

Sumber data dalam penelitian ini adalah berupa data sekunder yang berasal dari rakam medis pasien. Persetujuan penelitian dan penggunaan rekam medis telah disetujui oleh Kepala bagian SMF Anak di RSUD Wangaya Denpasar.

Data kemudian diolah, disajikan dalam bentuk tabel serta dilakukan analisis hasil. Dilakukan analisis Univariat untuk mendeskripsikan karakteristik responden dalam penelitian. Analisis Hubungan BBLR dengan kejadian asfiksia di ruang Nicu RSUD Wangaya Denpasar diuji dengan menggunakan uji statistik Chi Square. Analisis hubungan derajat BBLR dengan tingkat keparahan asfiksia neonatorum di RSUD Wangaya dengan menggunakan analisis Rank Spearman. Data diolah dengan Statistical Product and Service Solution (SPSS) 20 for Windows.

\section{HASIL}

Pada penelitian ini, pengambilan sampel dilakukan pada BBLR di RSUD Wangaya periode April 2016 April 2017 di ruang Nicu dan Perinatologi sampai jumlah sampel penelitian yang memenuhi kriteria inklusi dan eksklusi dengan jumlah sample total 87 sample. Berikut disajikan tabel deskripsi sampel berdasarkan karakteristik jenis kelamin, proses persalinan derajat BBLR, dan derajat Asfiksia neonatarum.

Persebaran sampel berdasarkan jenis kelamin menunjukkan persebaran yang cukup merata antara anak perempuan dan laki-laki dengan persentase 50,5\% dan 49,5\%. Proses persalinan terbanyak adalah section cesar yaitu $54,1 \%$ dibandingkan persalinan normal yaitu 45,9\%. Derajat BBLR pada Penelitian ini yang terbanyak adalah 
Tabel 1 Karakteristik Sampel Penelitian

\begin{tabular}{lcc}
\hline Variabel Penelitian & Frekuensi & $\%$ \\
\hline Jenis Kelamin & & \\
$\quad$ Laki-laki & 43 & 49,5 \\
$\quad$ Perempuan & 44 & 50,5 \\
Proses Persalinan & & \\
$\quad$ Normal & 40 & 45,9 \\
$\quad$ Sectio cesar & 47 & 54,1 \\
$\quad$ Derajat BBLR & & \\
$\quad$ BBLR & 58 & 66,7 \\
$\quad$ BBLSR & 29 & 33,3 \\
Derajat Asfiksia & & \\
$\quad$ Sedang & 53 & 60,8 \\
$\quad$ Berat & 34 & 39,2 \\
Total & 87 & 100,00 \\
\hline
\end{tabular}

Tabel 2 Pengaruh BBLR terhadap Asfiksia

\begin{tabular}{lcccc}
\hline Berat Badan lahir & Asfiksia Sedang & Asfiksia Berat & Total & P \\
\hline BBLR & $41(70,7 \%)$ & $17(29,3 \%)$ & $58(100 \%)$ & $0,03^{*}$ \\
BBLSR & $10(34,5 \%)$ & $19(65,5 \%)$ & $29(100 \%)$ & \\
Total & $51(58,6 \%)$ & $36(41,4 \%)$ & $87(100 \%)$ & \\
\hline
\end{tabular}

CI 95\%: 1,08-1,30

* uji chi square
Interprestasi Hasil:

$$
\begin{aligned}
\mathrm{RP}<1 \text { : } & \text { Bayi berat lahir sangat rendah } \\
& \text { merupakan factor protektif terha- } \\
& \text { dap Derajat asfiksia } \\
\mathrm{RP}=1 \text { : } & \text { Bayi berat lahir sangat rendah } \\
& \text { merupakan factor atau tidak } \\
& \text { berpengaruh terhadap derajat } \\
& \text { asfiksia } \\
\mathrm{RP}>1 & \text { Bayi berat lahir sangat rendah } \\
& \text { benar-benar merupakan factor } \\
& \text { resiko atau berpengaruh terhadap } \\
& \text { derajat asfiksia }
\end{aligned}
$$

Dari hasil perhitungan didapatkan resiko prevalensi sebesar 2,08 dimana dapat diinterprestasikan bahwa BBLR benar-benar merupakan factor resiko atau berpengaruh terhadap derajat asfiksia. Interval kepercayaan 95\% sebesar 1,08 - 1,30 dimana tidak mencakup angka 1, yang berarti dalam populasi hal tersebut diatas benar terjadi.

\section{DISKUSI}

Karakteristik sampel pada Penelitian ini antara lain, jenis kelamin, proses persalinan, derajat BBLR, derajat Asfiksia. Keseluruhan sampel berjumlah 87 sampel bayi.

Persebaran sampel berdasarkan jenis kelamin menunjukkan persebaran yang cukup merata antara anak perempuan dan laki-laki dengan persentase 50,5\% dan 49,5\%. Hasil penelitian ini sejalan dengan penelitian sebelumnya tahun 2012 di RSUD Kabupaten Karanganyar yaitu persentase jenis kelamin perempuan dan laki-laki 49,6\% dan $50,4 \%,{ }^{10}$ sedangkan dari beberapa penelitian ditemukan bahwa jenis kelamin bayi berpengaruh terhadap kejadian BBLR, seperti di Srilanka perbedaan berat badan bayi sebesar 58 gr antara bayi laki - laki dan perempuan dimana berat badan bayi laki - laki lebih berat di bandingkan dengan bayi perempuan. ${ }^{11}$

Proses persalinan terbanyak adalah section cesar yaitu 54,1\% dibandingkan persalinan normal yaitu $45,9 \%$. Hasil serupa juga didapatkan oleh Zanardo, peneliti mendapatkan risiko 2,6 kali untuk mengalami risiko kelainan pernapasan pada bayi yang dilahirkan melalui section caesarea jika dibandingkan melalui persalinan per vaginam. Peneliti menggunkan 1284 responden dengan operasi sectio caesarea elektif tanpa komplikasi yang diikuti 3 tahun sebelum melahirkan. Resiko ini meningkat jika analisis gangguan pernapasan dipisah berdasarkan jenis kelainannya. Resiko untuk terjadi respiratory distress syndrome meningkat menjadi 5,6 kali dan transient takipneu of newborn menjadi 2,8 kali. ${ }^{12}$ Melahirkan dengan 
alat, meconium pada cairan amnion, dan pecah ketuban yang berkepanjangan adalah faktor risiko asfiksia perinatal pada bayi baru lahir. ${ }^{13}$

Derajat BBLR pada Penelitian ini yang terbanyak adalah pada berat badan 1500 - 2500-gram sekitar $66,7 \%$. Hasil penelitian ini sejalan dengan penelitian sebelumnya tahun 2012 di RSUD Kabupaten Karanganyar yaitu persentase berat badan lahir terbanyak adalah 1500 - 2500-gram sekitar $85,6 \% .^{10}$ Bayi BBLR beresiko mengalami serangan apneu dan defesiensi surfaktan, sehingga tidak dapat memperoleh oksigen yang cukup yang sebelumnya diperoleh dari plasenta. ${ }^{14}$ Gangguan pernafasan sering menimbulkan penyakit berat pada Bayi Berat Lahir Rendah (BBLR). Hal ini disebabkan oleh kekurangan surfaktan, pertumbuhan dan pengembangan paru yang masih belum sempurna. Otot pernafasan yang masih lemah dan tulang iga yang mudah melengkung, sehingga sering terjadi apneu, asfiksia berat dan sindroma gangguan pernafasan. ${ }^{15}$

Penelitian ini dilakukan untuk mencari hubungan antara BBLR dengan derajat Asfiksia Neonatarum. Dari hasil penelitian ini didapatkan nilai $\mathrm{p}$ sebesar 0,03 . Karena nilai $\mathrm{p}<0,05$, maka dapat disimpulkan bahwa terdapat pengaruh yang signifikan antara BBLR dengan Derajat asfiksia. Dari hasil perhitungan didapatkan resiko prevalensi sebesar 2,08 dimana dapat diinterprestasikan bahwa BBLR benar-benar merupakan factor resiko atau berpengaruh terhadap derajat asfiksia. Interval kepercayaan 95\% sebesar 1,08 - 1,30 dimana tidak mencakup angka 1 , yang berarti dalam populasi hal tersebut diatas benar terjadi. Hasil penelitian ini sejalan dengan penelitian sebelumnya tahun 2012 di RSUD Kabupaten Karanganyar yang menunjukkan adanya pengaruh signifikan antara BBLR dengan derajat Asfiksia $(p=0,00) \cdot{ }^{10}$ Bayi dengan BBLR memiliki organ-organ yang kurang sempurna kematangannya, termasuk organ paru, sehingga dapat terjadi kekurangan surfaktan yang mengarah ke penyakit membran hialin (PMH). Bayi dengan BBLR mengalami pertumbuhan dan perkembangan paru kurang sempurna, reflek batuk, reflek menghisap dan reflek menelan yang kurang terkoordinasi, dan otot- otot bantu pernafasan yang lemah. Hal ini menyebabkan kesulitan bernafas dan berakibat terjadi asfiksia. ${ }^{16}$

\section{KETERBATASAN}

Data dalam penelitian ini masih menggunakan data sekunder dan pada penelitian ini variabel independen yang diteliti hanya terbatas pada
BBLR, sehingga beberapa faktor risiko lain dalam pustaka yang kemungkinan berhubungan dengan variabel dependen tidak dianalisis. Faktor risiko yang menyebabkan terjadinya asfiksia sangatlah bervariasi. Subyek dalam penelitian kurang variatif karena hanya mengambil dari satu rumah sakit sehingga tidak bisa digeneralisasikan serta waktu dalam pengumpulan sampel yang cukup singkat.

\section{SIMPULAN}

Pasien BBLR di ruang NICU dan Perinatologi di RSUD Wangaya persebaran jenis kelamin laki-laki dan perempuan cukup merata. Didapatkan persalinan dengan SC menunjukkan persentase yang lebih tinggi dibandingkan persalinan normal yaitu $54,1 \%$. Terdapat pengaruh yang signifikan antara BBLR terhadap derajat Asfiksia di RSUD Wangaya Kota Denpasar.

Diharapkan dapat dilakukan penelitian lebih lanjut mengenai faktor-faktor yang mempengaruhi terjadinya asfiksia selain BBLR sehingga diketahui faktor yang paling berpengaruh. Diharapkan dapat dilakukan penelitian menggunakan metode yang lebih kuat dengan jumlah sampel yang lebih besar serta waktu penelitian yang lebih panjang, sehingga diperoleh hasil yang lebih mewakili dan dapat direpresentasikan dengan lebih baik pada populasi.

\section{DAFTAR PUSTAKA}

1. IDAI. Asfiksia Neonatorum. Dalam: Standar Pelayanan Medis Kesehatan Anak. Jakarta: Badan Penerbit Geneva: World Health Organization. 1999. Diunduh dari: www. who.int/reproductivehealth/publications/newborn_resus_ citation/index.html

2. Departemen Kesehatan RI. Survei Demografi dan Kesehatan Indonesia. Jakarta. 2012.

3. Djaja S, Hapsari D, Sulistyawati N, \& Lolong BD. Peran Faktor Sosio Ekonomi Biologi dan Pelayanan Kesehatan terhadap Kesakitan dan Kematian Neonatal. Maj Kedokteran Indonesia. 2009. vol 59.

4. Efriza. Determinan Kematian Neonatal Dini di RSUD. Dr. Achmad Mochtar Bukittinggi. Jurnal kesehatan Masyarakat Nasional. 2007. Vol 2 No 3.

5. Depkes RI. Profil Kesehatan 2007. Departemen Kesehtan RI. 2007.

6. Depkes RI. Riset Kesehatan Dasar. Jakarta: Badan Penelitian dan pengembangan Kesehatan Kementrian Kesehatan RI. 2013.

7. Dinkes Denpasar. Profil Kesehatan Kota Denpasar 2013. Dinas Kesehtan Kota Denpasar. 2013.

8. Dewi VNL. Asuhan Neonatus Bayi dan Anak Balita. Jakarta: Salemba Medika. 2010.

9. Proverawati A. BBLR (Berat Badan Lahir Rendah). NuhaMedika, Yogyakarta. 2010.

10. Departemen Kesehatan Provinsi Jawa Tengah. Profil Kesehatan Provinsi Jawa Departemen Kesehatan Provinsi Jawa Tengah. Semarang. 2012. 
11. Gilstrap LC. American Academy of Pediatrics and American College of Obstetricians and Gynaecologists. Care of the neonate. Guidelines for perinatal care. Elk Grove Village (IL): American Academy of Pediatrics; 2002: 196-7.

12. Cunningham FG, Gant NF, Leveno KJ, Gilstrap LC, Hauth JC, Wenstrom, KD. Obstetri Williams. Edisi 21. Jakarta: EGC. 2005

13. Kardana I. Risk Factors of Perinatal Asphyxia in The Term Newborn at Sanglah General Hospital, Bali-Indonesia. Bali Medical Journal. 2016. 5(1): 175-178. DOI: 10.15562/bmj. v5i1.312

14. Mochtar, Rustam. Sinopsis Obstetri. Jakarta.EGC. 2000.
15. Wiknjosastro H, Bari S A, Rachimhadhi T. Ilmu kebidanan. Yayasan Bina Pustaka Sarwono Prawirohardjo, Jakarta. Edisi 3. Cetakan 5. 1999.

16. Ikatan Dokter Anak Indonesia (IDAI). Bayi berat lahir rendah. Dalam : standar pelayanan medis kesehatan anak. Ed I. Jakarta. 2004

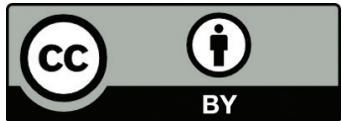

This work is licensed under a Creative Commons Attribution 